\title{
Apis mellifera pollen loads to understand the pollen foraging pattern used for apicultural practice in a potentially agricultural belt in Bengal, India
}

\author{
Tripti Nandi \& Prakash Karmakar* \\ Department of Botany and Forestry, Vidyasagar University, Midnapore- 721102, India; nanditripti@gmail.com, \\ karmakar_p@yahoo.co.in \\ * Correspondence
}

Received 12-III-2018. $\quad$ Corrected 21-VIII-2018. $\quad$ Accepted 24-IX-2018.

\begin{abstract}
For accurate determination of polleniferous taxa vis-a-vis floral fidelity of Apis mellifera L. in North 24 Pargana, West Bengal, we carried out pollen analyses of individual corbicular pollen loads collected from four apiaries during 2015-2016. Among the 2434 analyzed loads, $72.97 \%$ were unifloral type, $19.0 \%$ bifloral and $8.10 \%$ were multifloral in pollen composition. We identified 43 different types of palynomorphs belonged to 28 botanical families. Major polleniferous plant species include: Alangium salviifolium, Borassus flabellifer, Brassica nigra, Coriandrum sativum, Croton bonplandianum, Cyanotis axillaris, Luffa cylindrica, Neolamarckia cadamba, Phoenix sylvestris, Poa gangetica, Sesamum indicum and Trema orientalis. Among them, T. orientalis is newly reported from West Bengal especially during June to August (monsoon season). The plant family provided maximum number of loads was Arecaceae $(20.91 \%)$, followed by Brassicaceae $(16.2 \%)$, Poaceae $(6.70 \%)$, Pedaliaceae $(6.38 \%)$, Apiaceae $(6.16 \%)$ and Fabaceae $(5.38 \%)$. Month wise highest number of pollen diversity were obtained during March (13 pollen types) and a minimum of 6 types in November. The present investigation will help the beekeepers to maintain their hives in the region for sustainable apicultural practices.
\end{abstract}

Kew words: beekeeping; floral fidelity; pollen load; polleniferous flora.

Nandi, T., \& Karmakar, P. (2018). Apis mellifera pollen loads to understand the pollen foraging pattern used for apicultural practice in a potentially agricultural belt in Bengal, India. Revista de Biología Tropical, 66(4), 1597-1605.

Pollen is the bee's major sources of proteins, amino acids, lipids, minerals and vitamins (Marchini, Reis, \& Moreti, 2006). It is essential for the growth of larvae and young adult bees (Dietz, 1975; Modro, Silva, Cynthia, Luz, \& Message, 2009). Rearing one worker bee from larval to adult stage requires approximately 120-145 mg of pollen (Alfonsus, 1933; Haydak, 1935). Honeybee transports pollen to the hive in specialised structures of its legs (corbicula), in which pollen moistened with nectar and hypopharyngeal and mandibular secretions, is packaged forming pasty pellets called 'pollen loads' (Thorp, 2000). The pollen composition in the pollen loads is a reflection of the local flora preferred by the workers of the bee species surrounding hives (DiazLosada, Ricciardelli-d'Albore, \& Saa-Otero, 1998). Therefore determination of polleniferous flora in a given area is very important for development of any apiculture industry (Sajwani, Farooq, \& Bryant, 2014). In West Bengal some work on polleniferous flora was done by Pal and Karmakar (2013), More, Ghorai, \& Bera, 2010. Though few works on pollen analyses of $A$. mellifera form outside the state as well as from other countries were reported by Suryanarayana, Rao, \& Singh, 1992; Noor, 
Khan, \& Camphor, 2009; Lopez, Vives, \& Boi, 2013; Saavedra-Carhuatacto, Aguinago-Castro, Rojas-Indrogo, \& Delgado-Paredes, 2014 and Freitas, Sattler, Souza, Almeida-Muradian, Sattler, \& Barth, 2015.

The present study aims to investigate the botanical origin of pollen loads collected in North 24 Parganas district, West Bengal to provide a guide to the optimal utilization of floral resources by honeybees for sustainable apiculture industries.

\section{MATERIALS AND METHODS}

Study site: North 24 Pargana is a district in southern West Bengal of Eastern India. The district situated between $\left(22^{\circ} 11^{\prime}-23^{\circ} 15^{\prime} \mathrm{N}\right.$ $\& 88^{\circ} 20^{\prime}-89^{\circ} 5^{\prime}$ E) with a total area of 4094 $\mathrm{km}^{2}$. The climatic condition is tropical and experiences hot, humid and exhausting summer (mid April-mid June) with daily temperature ranging from $20{ }^{\circ} \mathrm{C}$ to $40{ }^{\circ} \mathrm{C}$. The next season is monsoon which continued up to August, with an average annual rainfall of $1579 \mathrm{~mm}$ and with high relative humidity level (RH 90 $\%$ ). The cold and dry winter approach in early
December and stay up to mid February with day temperature ranges from 8 to $28^{\circ} \mathrm{C}$. Major rivers flows through the district are Ganges, Ichhamati, Jamuna and Bidyadhari. The soil of the northern part of the district is sandy, in the central middle part it is sandy and clay loam and in the southern side it is clay loam. The area harbours a diversified flora with a productive agricultural output as the river Ganges flows its long course through the district.

Collection of samples: A total of 2434 pollen loads were collected from four apiaries viz. Amdanga (634 pollen loads), Bagdaha (586 pollen loads), Barrackpur (610 pollen loads) and Haripur (604 pollen loads) located at four different areas of North 24 Parganas district, West Bengal (Fig. 1). Pollen samples were collected for 12 months (January to December) and three to four sampling days per month. 30 to 64 loads were collected for each sampling day from one apiary. Incoming pollen foragers were captured at the entrance of the hive, and the two corbicular loads were collected. Pollen loads were preserved separately in $(5 \mathrm{~mL})$ white glass vials containing FAA (FormalinAceto-Alcohol, 5:5:90) solution.

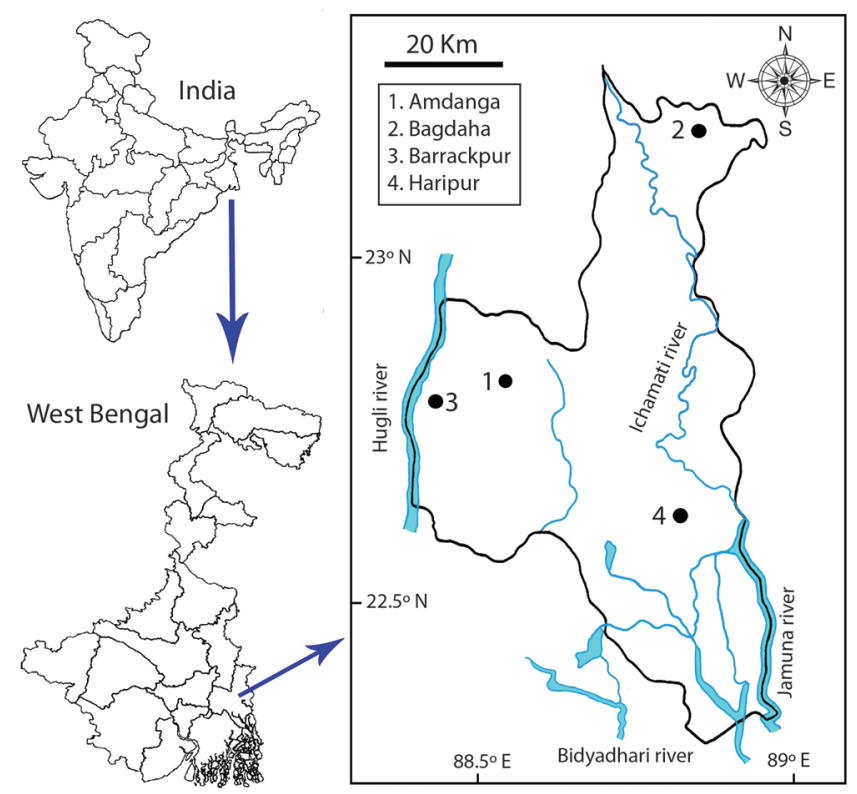

Fig. 1. Location areas of collection of bee pollen load for analysis. 
Palynological analyses: Each pollen load was analyzed separately. The pollen loads were suspended in $50 \mathrm{~mL}$ of $95 \%$ ethanol and thoroughly mixed (Jones \& Bryant, 2004). The final suspension was then centrifuged at 4000 rpm for $5 \mathrm{~min}$. After decanting supernatant, the sediment was subjected to acetolysis (Erdtman, 1960) with a 9:1 ratio of acetic anhydride to conc. sulphuric acid. After thoroughly mixing, the mixture containing tube was placed into a water bath (at $80{ }^{\circ} \mathrm{C}$ ) for $3 \mathrm{~min}$. Then $5 \mathrm{~mL}$ of glacial acetic acid was added to each sample. The samples were rinsed twice with distilled water, centrifuging and decanting each time, and then once with $95 \%$ ethyl alcohol. After centrifuging, the pellet was taken on a small piece of glycerine jelly and transferred to the centre of a glass slide. Glycerine jelly was used as a mounting medium to prepare the samples for light microscopy (Ohe, Oddo, Piana, Morlot, \& Martin, 2004). Then warmed gently to melt the jelly containing pollen sediment and covered by cover glass and sealed with paraffin wax. Identification of pollen types was done (on the basis of 500 grains counted per slide) with the help of reference slides prepared from the local flora as well as from published accounts (Nayar, 1990; Layek \& Karmakar, 2016). Analysis was conducted using Leica DM1000 and photomicrographs of suitable magnifications were made with Leica DFC295
Digital camera. The contents of each pollen load were designated as being unifloral (with single pollen type $\geq 90 \%$ ), bifloral (with pollen of two types, one $80-90 \%$ and other $20-10 \%$ ) and multifloral (with pollen of more than two types $\geq 10 \%$ ). Month wise percentages of the pollen types were also determined. Then we classified the obtained pollen types into three groups: very frequent $(>20 \%)$, frequent (10$20 \%$ ) and less frequent $(<10 \%)$ (Layek \& Karmakar, 2018).

Data Analysis: Statistical analyses of the pollen materials were done to get the arithmetic mean and standard deviation. To assess the association between different variables we followed Kearl Pearson's correlation coefficient method.

\section{RESULTS}

The analyzed pollen loads were designated as unifloral, bifloral and multifloral according to their pollen composition. The overall number of unifloral loads was 1776 (72.97\%), bifloral was $462(18.98 \%)$ and multifloral was 196 (8.05\%). Among the multifloral loads, the majority had three pollen types and only eight loads were with four pollen types in composition. The highest proportion of unifloral loads was recorded during April (89.8 \%), followed

TABLE 1

Pollen loads of A. mellifera collected in North 24-Parganas, West Bengal (India)

\begin{tabular}{lcccc}
\multicolumn{1}{c}{ Months } & No. of loads analyzed & Percentages of different types of pollen load (mean \pm std. deviation) \\
January & 226 & Unifloral & Bifloral & Multifloral \\
February & 242 & $82.3 \pm 4.2$ & $13.2 \pm 2.7$ & $4.4 \pm 1.5$ \\
March & 244 & $79.3 \pm 8.9$ & $14.9 \pm 3.4$ & $5.8 \pm 5.7$ \\
April & 216 & $86.0 \pm 4.3$ & $11.5 \pm 2.1$ & $2.4 \pm 3.1$ \\
May & 184 & $89.4 \pm 4.7$ & $5.5 \pm 2.1$ & $5.0 \pm 4.1$ \\
June & 120 & $61.3 \pm 7.6$ & $28.9 \pm 4.9$ & $9.8 \pm 4.1$ \\
July & 166 & $53.3 \pm 9.4$ & $35.0 \pm 6.4$ & $11.6 \pm 6.4$ \\
August & 202 & $50.5 \pm 4.2$ & $39.9 \pm 7.1$ & $9.5 \pm 3.3$ \\
September & 188 & $50.1 \pm 5.6$ & $31.7 \pm 2.9$ & $18.1 \pm 4.3$ \\
October & 210 & $65.0 \pm 4.3$ & $20.2 \pm 0.4$ & $14.8 \pm 4.4$ \\
November & 214 & $71.0 \pm 5.4$ & $17.1 \pm 3.4$ & $11.9 \pm 5.9$ \\
December & 222 & $84.1 \pm 7.8$ & $12.0 \pm 6.5$ & $3.9 \pm 2.9$ \\
\hline
\end{tabular}


by March (86.1\%), November (85.05\%), January $(82.30 \%)$, December $(80.18 \%)$, February $(79.34 \%)$, October $(71.4 \%)$, September (64.89\%), May (61.96\%), June (53.33\%), July (50.60\%) and August (49.50\%). The sequences were almost reverse in cases of bifloral and multifloral loads (Table 1, Fig. 2). A total of 43 pollen types belonging to 28 plant families were identified (Table 2). Month wise analysis of loads revealed highest number of pollen types during March (13 types), followed by July (11 types), February, June and August (each of them with ten types), January, April, May and September (each with 8 types), October and December (both of each with seven types), and November with 6 pollen types (Table 2). According to frequency classes very frequent $(>20 \%)$ pollen types were Brassica nigra, Phoenix sylvestris (during January); Coriandrum sativum (in February); Borassus flabellifer (during March and April); Sesamum indicum (in May); Acacia auriculiformis, Cocos nucifera (in September); Cocos nucifera, Poa gangetica (in October) and Brassica nigra during November and December. Besides the above mentioned pollen types, other frequent pollen types were Alangium salviifolium, Citrus $\times$ aurantiifolia, Citrus maxima, Croton bonplandianum, Cyanotis axillaris, Luffa cylindrica, Neolamarckia cadamba and Trema orientalis. Plants that accounted for the higher number of pollen loads were Brassica nigra (7.59 \%), followed by Cocos nucifera (4.57\%), Poa gangetica (3.34\%), Borassus flabellifer (3.20\%), Sesamum indicum (3.19 $\%)$, Coriandrum sativum (3.08 \%), Phoenix sylvestris $(2.68 \%)$, Trema orientalis $(2.37 \%)$ and Acacia auriculiformis (2.16 \%). Plant families that accounted for a large number of loads were Arecaceae (21\%), Brassicaceae (16.23 $\%)$, Poaceae $(6.68 \%)$, Pedaliaceae $(6.38 \%)$, Apiaceae (6.16\%) and Fabaceae (5.38 \%). The families that represented the greater number of taxa were Asteraceae and Euphorbiaceae (each of them with 4 plant taxa); followed by Arecaceae and Cucurbitaceae (each with 3 plant taxa); each of the family viz. Brassicaceae, Fabaceae, Myrtaceae and Rutaceae represented by 2 plant taxa. The remaining 20 families represented by single plant taxon.

\section{DISCUSSION}

Major proportion of unifloral loads implies the floral fidelity behaviour of the bee species. Bifloral and multifloral loads could be due to the variety of flowering plants that were blooming simultaneously. This multifloral availability appears to divert the attention of some foraging bees (Alves \& Santos 2014). Greater proportion of unifloral loads were obtained during March-April (spring-summer) and NovemberJanuary (winter) derived from Borassus flabellifer and Brassica nigra, Phoenix sylvestris respectively. The importance of these plant taxa as polleniferous plant were also reported by Layek, Nandi, \& Karmakar (2016) form West Bengal and Suryanarayana et al. (1992) from Bihar in India. In addition to the above mentioned taxa, other important polleniferous plants were: Acacia auriculiformis, Cocos nucifera, Coriandrum sativum, Poa gangetica, Sesamum indicum and Trema orientalis. The significance of some the above taxa as pollen contributor were also recorded in India as well as from other countries (by Noor et al., 2009; Karmakar, Layek, \& Pal, 2011; Layek, Bhakat, \& Karmakar, 2015). But the significance of Trema orientalis as polleniferous plant was not previously recorded by any author in West Bengal, India. The small percentage of pollen from: Bombax ceiba, Euphorbia tithymaloides, Flacourtia jangomas, Litchi chinensis, Nelumbo nucifera, Tridax procumbens indicate that these plants are either sporadic in distribution, fairly rare in abundance, do not produce sufficient amount of pollen for bee foraging, or produce pollen that is not preferred by honeybees due to low nutritional value (Dórea, Novais \& Santos, 2010). Among the major pollen supplied families, Apiaceae, Pedaliaceae and Poaceae comprises of single plant taxon. On the other hand, largest represented families Asteraceae, Cucurbitaceae and Euphorbiaceae contributed moderate pollen to the bee species. Hence, the correlation between represented plant taxa of a 

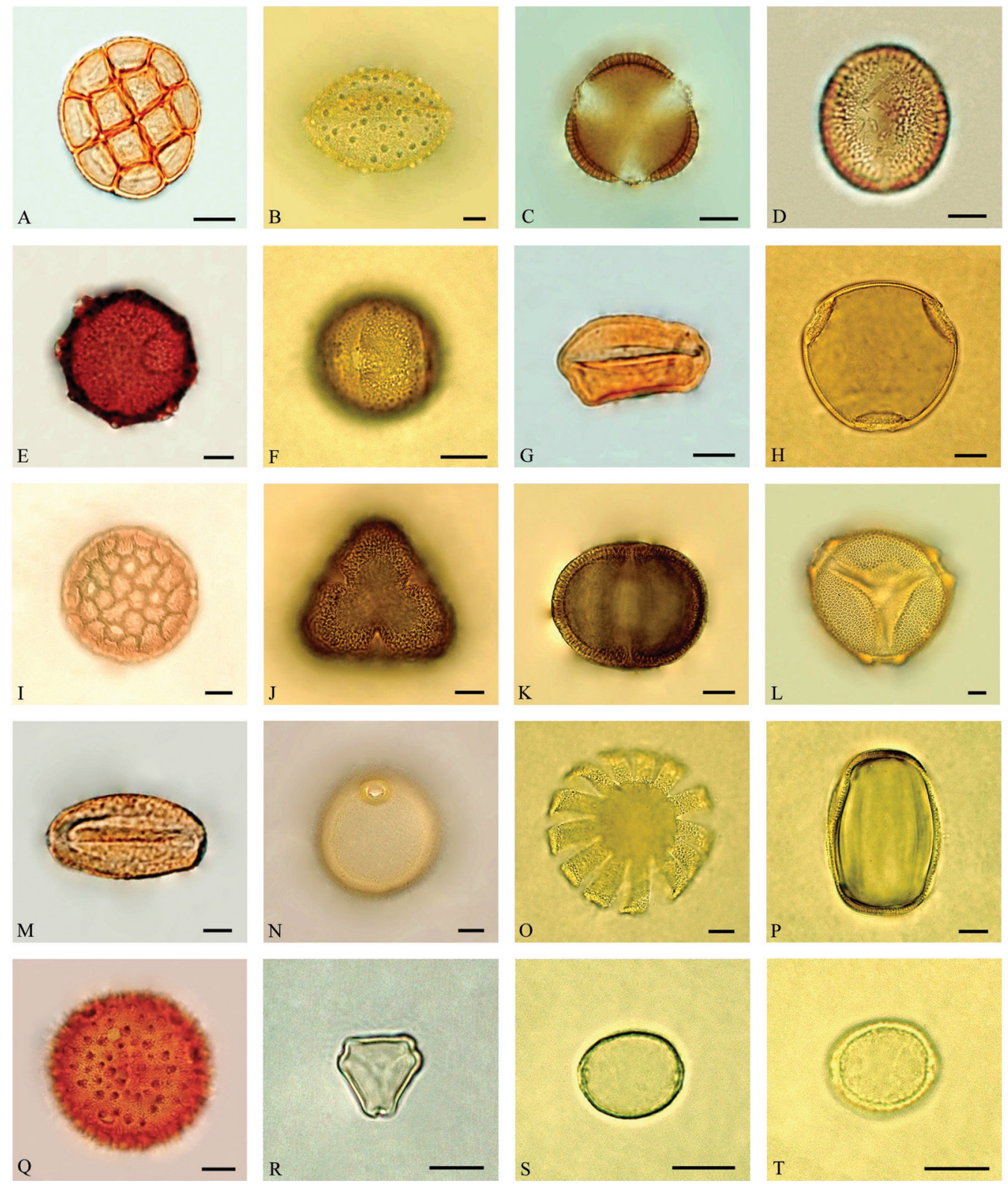

Fig. 2. Some pollen types obtained from pollen loads of Apis mellifera: A) Acacia auriculiformis; B) Borassus flabellifer; C, D) Brassica nigra; E) Chrozophora rottleri; F) Citrus x aurantiifolia; G) Cocos nucifera; H) Cucumis sativus; I) Delonix regia; J, K) Euphorbia tithymaloides; L) Luffa cylindrical; M) Monochoria hastate; N) Poa gangetica; O, P) Sesamum indicum; Q) Sida acuta; R) Syzygium cumini; S, T) Trema orientalis.

Scale bars $=10 \mu \mathrm{m}$. 
TABLE 2

Pollen types obtained from loads of Apis mellifera in North 24 Parganas, West Bengal (India)

\begin{tabular}{|c|c|c|c|c|c|c|c|c|c|c|c|c|c|}
\hline \multirow{2}{*}{ Pollen types } & \multicolumn{12}{|c|}{ Months } & \multirow{2}{*}{ No. of loads } \\
\hline & Jan & Feb & Mar & Apr & May & Jun & Jul & Aug & Sep & Oct & Nov & Dec & \\
\hline Amaranthaceae & & & & & & & & & & & & & 7 \\
\hline Amaranthus spinosus & & & & & & & LF & LF & & & & & 7 \\
\hline Apiaceae & & & & & & & & & & & & & 75 \\
\hline Coriandrum sativum & $\mathrm{F}$ & VF & & & & & & & & & & $\mathrm{F}$ & 75 \\
\hline Arecaceae & & & & & & & & & & & & & 254.49 \\
\hline Borassus flabellifer & & & VF & VF & & & & & & & & & 78 \\
\hline Cocos nucifera & LF & $\mathrm{LF}$ & $\mathrm{LF}$ & & & LF & $\mathrm{F}$ & $\mathrm{F}$ & VF & VF & & LF & 111.32 \\
\hline Phoenix sylvestris & VF & $\mathrm{F}$ & & & & & & & & & & $\mathrm{F}$ & 65.17 \\
\hline Asparagaceae & & & & & & & & & & & & & 11.50 \\
\hline Polianthes tuberosa & & & & & & & LF & LF & & & & & 11.50 \\
\hline Asteraceae & & & & & & & & & & & & & 36.83 \\
\hline Helianthus annuus & & $\mathrm{LF}$ & $\mathrm{LF}$ & & & & & & & & & & 8 \\
\hline Mikania scandens & LF & & & & & & & & & & $\mathrm{LF}$ & LF & 16.33 \\
\hline Tagetes erecta & $\mathrm{LF}$ & & & & & & & & & & & LF & 8 \\
\hline Tridax procumbens & & & & & & LF & & & & & & & 4.50 \\
\hline Brassicaceae & & & & & & & & & & & & & 197.50 \\
\hline Brassica nigra & VF & F & $\mathrm{LF}$ & & & & & & & & VF & VF & 184.67 \\
\hline Raphanus sativus & LF & & & & & & & & & & & LF & 12.83 \\
\hline Cannabaceae & & & & & & & & & & & & & 57.67 \\
\hline Trema orientalis & & & & $\mathrm{LF}$ & $\mathrm{LF}$ & $\mathrm{F}$ & $\mathrm{F}$ & F & LF & & & & 57.67 \\
\hline Capparaceae & & & & & & & & & & & & & 11 \\
\hline Capparis zeylanica & & & $\mathrm{LF}$ & LF & & & & & & & & & 11 \\
\hline Cleomaceae & & & & & & & & & & & & & 7.33 \\
\hline Cleome viscosa & & & & & & $\mathrm{LF}$ & LF & & & & & & 7.33 \\
\hline Combretaceae & & & & & & & & & & & & & 10 \\
\hline Terminalia arjuna & & & & LF & & & & & & & & & 10 \\
\hline Commelinaceae & & & & & & & & & & & & & 17.67 \\
\hline Cyanotis axillaris & & & & & & $\mathrm{LF}$ & LF & & LF & $\mathrm{F}$ & $\mathrm{LF}$ & & 17.67 \\
\hline Cornaceae & & & & & & & & & & & & & 27.67 \\
\hline Alangium salviifolium & & & $\mathrm{F}$ & LF & & & & & & & & & 27.67 \\
\hline Cucurbitaceae & & & & & & & & & & & & & 61.67 \\
\hline Cucumis sativus & & & & & & & LF & LF & LF & & & & 21 \\
\hline Cucurbita maxima & & & LF & & & & & & & & & & 5.50 \\
\hline Luffa cylindrica & & & $\mathrm{LF}$ & & LF & $\mathrm{F}$ & LF & LF & LF & & & & 35.17 \\
\hline Euphorbiaceae & & & & & & & & & & & & & 45.17 \\
\hline Chrozophora rottleri & & & & & LF & LF & & & & & & & 9.17 \\
\hline Croton bonplandianum & & & & LF & LF & $\mathrm{F}$ & & & & & & & 22 \\
\hline Euphorbia tithymaloides & & & & & LF & & & & & & & & 2 \\
\hline Ricinus communis & & & & & & & & & LF & LF & & & 12 \\
\hline Fabaceae & & & & & & & & & & & & & 65.50 \\
\hline Acacia auriculiformis & & & & & & & LF & LF & $\mathrm{VF}$ & LF & & & 52.50 \\
\hline Delonix regia & & & & LF & LF & & & & & & & & 13 \\
\hline Malvaceae & & & & & & & & & & & & & 10.17 \\
\hline Bombax ceiba & & & $\mathrm{LF}$ & & & & & & & & & & 3.17 \\
\hline Sida acuta & & & & & & & & & & LF & LF & & 7 \\
\hline
\end{tabular}


CUADRO 2 (Continuación) / TABLE 2 (Continued)

\begin{tabular}{|c|c|c|c|c|c|c|c|c|c|c|c|c|c|}
\hline \multirow{2}{*}{ Pollen types } & \multicolumn{12}{|c|}{ Months } & \multirow{2}{*}{ No. of loads } \\
\hline & Jan & Feb & Mar & Apr & May & Jun & Jul & Aug & Sep & Oct & Nov & Dec & \\
\hline Moringaceae & & & & & & & & & & & & & 6.33 \\
\hline Moringa oleifera & LF & LF & & & & & & & & & & & 6.33 \\
\hline Myrtaceae & & & & & & & & & & & & & 28.83 \\
\hline Eucalyptus globulus & & & & & & & & & & LF & LF & LF & 22.83 \\
\hline Syzygium cumini & & & LF & & & & & & & & & & 6 \\
\hline Nelumbonaceae & & & & & & & & & & & & & 2.50 \\
\hline Nelumbo nucifera & & & & & LF & & & & & & & & 2.50 \\
\hline Pedaliaceae & & & & & & & & & & & & & 77.67 \\
\hline Sesamum indicum & & & & $\mathrm{F}$ & VF & & & & & & & & 77.67 \\
\hline Poaceae & & & & & & & & & & & & & 81.33 \\
\hline Poa gangetica & & & & & & & & $\mathrm{F}$ & LF & VF & $\mathrm{F}$ & & 81.33 \\
\hline Pontederiaceae & & & & & & & & & & & & & 7.67 \\
\hline Monochoria hastata & & & & & & & & LF & & & & & 7.67 \\
\hline Ranunculaceae & & & & & & & & & & & & & 8.33 \\
\hline Nigella sativa & & LF & & & & & & & & & & & 8.33 \\
\hline Rubiaceae & & & & & & & & & & & & & 21.84 \\
\hline Neolamarckia cadamba & & & & & & LF & $\mathrm{F}$ & LF & & & & & 21.84 \\
\hline Rutaceae & & & & & & & & & & & & & 32.17 \\
\hline Citrus $\times$ aurantiifolia & & & & & & LF & $\mathrm{F}$ & & & & & & 11 \\
\hline Citrus maxima & & LF & $\mathrm{F}$ & & & & & & & & & & 21.17 \\
\hline Salicaceae & & & & & & & & & & & & & 5 \\
\hline Flacourtia jangomas & & & LF & & & & & & & & & & 5 \\
\hline Sapindaceae & & & & & & & & & & & & & 1.50 \\
\hline Litchi chinensis & & LF & & & & & & & & & & & 1.50 \\
\hline Ulmaceae & & & & & & & & & & & & & 18.50 \\
\hline Holoptelea integrifolia & & LF & LF & & & & & & & & & & 18.50 \\
\hline No. of pollen types & 8 & 10 & 13 & 8 & 8 & 10 & 11 & 10 & 8 & 7 & 6 & 8 & \\
\hline
\end{tabular}

VF: very frequent, F: frequent, LF: less frequent.

family and their contribution as pollen supplier is low to medium ( $\mathrm{r}=0.40, \mathrm{n}=28)$.

The present study was undertaken to identify the polleniferous flora of the study area as well as floral fidelity behaviour of the bee species. Regarding pollen composition of each load, it was found that majority were unifloral type which signifies the floral fidelity behaviour of the bee species. Floral constancy level increases with the presence of excellent and huge polleniferous plants during March-April and November-January, whereas decreases during dearth period from June-August due to absence of very frequent pollen types in these regions. However, Trema orientalis play a major role to sustain the pollen flow for the bee colony during the dearth period in the studied area. The present work provides us with a considerable knowledge about plant diversity and the annual flowering pattern. By knowing the flowering pattern and the preferred plant species for pollen collection by A. mellifera, the apiculturists will get a proper knowledge regarding successful establishment of apiaries in that region.

Ethical statement: authors declare that they all agree with this publication and made significant contributions; that there is no conflict of interest of any kind; and that we 
followed all pertinent ethical and legal procedures and requirements. A signed document has been filed in the journal archives.

\section{ACKNOWLEDGMENTS}

We are thankful to authorities of Vidyasagar University for providing necessary laboratory and internet facilities. We are also grateful to Apiarists for help us during collection of pollen loads of the bee species. Thanks are also due to Ujjwal Layek for helping us by preparing the tables and photo plates of the manuscript.

\section{RESUMEN}

Cargas polínicas de Apis mellifera para entender los patrones de forrajeo de polen usados en apicultura en una franja potencialmente agrícola en Bengala, India. Para una determinación precisa de taxa polinífero y fidelidad floral de Apis mellifera en Pargana Norte 24, Bengala Occidental, realizamos análisis de cargas individuales de polen corbicular, recolectados en cuatro apiarios durante 2015-2016. De las 2434 cargas analizadas, 72.97 $\%$ fueron de tipo unifloral, $19.0 \%$ bifloral y $8.10 \%$ multifloral, en la composición del polen. Identificamos 43 tipos diferentes de palinomorfos pertenecientes a 28 familias botánicas. Las especies principales de plantas poliníferas incluyen: Alangium salviifolium, Borassus flabellifer, Brassica nigra, Coriandrum sativum, Croton bonplandianum, Cyanotis axillaris, Luffa cylindrica, Neolamarckia cadamba, Phoenix sylvestris, Poa gangetica, Sesamum indicum y Trema orientalis. Entre estas, T. orientalis ha sido reportada recientemente en Bengala Occidental, especialmente de junio a agosto (temporada de monsones). La familia de plantas que presentó máxima cantidad de cargas fue: Arecaceae $(20.91 \%)$, seguida por Brassicaceae (16.2 \%), Poaceae $(6.70 \%)$, Pedaliaceae $(6.38 \%)$, Apiaceae $(6.16 \%)$ y Fabaceae $(5.38 \%)$. De acuerdo al mes, el número mayor de diversidad de polen se obtuvo durante marzo (13 tipos de polen) y un mínimo de seis tipos en noviembre. La presente investigación ayudará a los apicultores a mantener sus colmenas en la región para prácticas apícolas sostenibles.

Palabras clave: apicultura; fidelidad floral; carga polínica; flora polinífera.

\section{REFERENCES}

Alfonsus, E. O. (1933). Zum Pollenverbrauch des Bienenvolkes. Archivfur Bienenkunde, 14, 220-223.
Alves, R. F., \& Santos, F. A. R. (2014). Plant sources for bee pollen load production in Sergipe, northeast Brazil. Palynology, 38(1), 90-100.

Diaz-Losada, E., Ricciardelli-d'Albore, G., \& Saa-Otero, M. P. (1998). The possible use of honeybee pollen loads in characterising vegetation. Grana, 37, 155-163.

Dietz, A. (1975). Nutrition of the adult honeybee. In Dadant \& Sons (Eds.), The Hive and the Honey Bee (pp. 125-156). Hamilton, IL: Dadant and Sons.

Dórea, M. C., Novais, J. S., \& Santos, F. A. R. (2010). Botanical profile of bee pollen from the southern coastal region of Bahia, Brazil. Nota Cientifica. Acta Botanica Brasilica, 24(3), 862-867.

Erdtman, G. (1960). The acetolysis method. A revised description. Svensk Botanisk Tidskrift, 54, 561-564.

Freitas, A. D. S. D., Sattler, J. A. G., Souza, B. R. D., Almeida-Muradian, L. B., Sattler, A., \& Barth, O. M. (2015). A melissopalynological analysis of Apis mellifera L. loads of dried bee pollen in the southern Brazilian macro-region. Grana, 54(4), 305-312.

Haydak, M. H. (1935). Brood rearing by honeybees confined to pure carbohydrate diet. Journal of Economic Entomology, 29, 657-660.

Jones, G. D., \& Bryant, V. M. Jr. (2004). The use of ETOH for the dilution of honey. Grana, 43, 174-182.

Karmakar, P., Layek, U., \& Pal, P. K. (2011). Sesamum indicum L., a potential bee plant in Bankura and Paschim Medinipur district, West Bengal. Journal of the Botanical Society of Bengal, 65(1), 69-74.

Layek, U., Bhakat, R. K., \& Karmakar, P. (2015). Foraging behaviour of Apis florea Fabricius during winter and spring-summer in Bankura and Paschim Medinipur districts, West Bengal. Global Journal of Bio Sciences and Biotechnology, 4(3), 255-263.

Layek, U., \& Karmakar, P. (2016). Bee plants used as nectar sources by Apis florea Fabricius in Bankura and Paschim Medinipur districts, West Bengal. Geophytology, 46(1), 1-14.

Layek, U., \& Karmakar, P. (2018). Pollen analysis of Apis dorsata Fabricius honeys in Bankura and Paschim Medinipur districts, West Bengal. Grana. 57(4), 298310. DOI: 10.1080/00173134.2017.1390604.

Layek, U., Nandi, T., \& Karmakar, P. (2016). Pollen forage and storage pattern of Apis dorsata Fabricius in Bankura and Paschim Medinipur districts, West Bengal. International Journal of Pure and Applied Bioscience, 4(5), 59-71.

Lopez, J. M. V., Vives, L. G., \& Boi, M. (2013). Estimation of the polleniferous potential of a Mediterranean 
landscape through the analysis of pollen harvested by Apis mellifera L. Grana, 52(2), 147-159.

Marchini, L. C., Reis, V. D. A., \& Moreti, A. C. C. C. (2006). Composicao fisico-quimica de amostras de pollen coletado por abelhas africanizadas Apis mellifera (Hymenoptera: Apidae) em Piracicaba, Estado de Sao Paulo. Ciencia Rural, 36(3), 949-953.

Modro, F. H. A., Silva, C. I., Cynthia, F. P., Luz, F. P. C., \& Message, D. (2009). Analysis of pollen load based on color, physicochemical composition and botanical source. Anais da Academia Brasileira de Ciências, 81(2), 281-285.

More, S., Ghorai, N., \& Bera, S. (2010). Study on the selection of some local pollen plants in West Bengal, India as pollen brood feed in Apis cerana Fabr. larvae by the worker bees, through Meconia analysis and community ordination method of recovered pollen taxa. Proceedings of the Zoological Society, 63(1), 39-44.

Nayar, T. S. (1990). Pollen flora of Maharashtra state, India. International Bioscience Series, 14.

Noor, M. J., Khan, M. A., \& Camphor, E. S. (2009). Palynological analysis of pollen loads from pollen sources of Honeybees in Islamabad, Pakistan. Pakistan Journal of Botany, 41(2), 495-501.
Ohe, W. V. D., Oddo, L. P., Piana, M. L., Morlot, M., \& Martin, P. (2004). Harmonized methods of melissopalynology. Apidologie, 35, 18-25. DOI: 10.1051/ apido: 2004050

Pal, P. K., \& Karmakar, P. (2013). Pollen analysis in understanding the foraging behaviour of Apis mellifera in Gangetic West Bengal. Geophytology, 42(2), 93-114.

Saavedra-Carhuatacto, D. M., Aguinago-Castro, F., RojasIndrogo, C., \& Delgado-Paredes, G. E. (2014). Analysis of pollen loads collected by honey bees (Apis mellifera L.) from Lambayeque Province (Peru): botanical origin and protein content. Journal of Global Biosciences, 3(1), 285-298.

Sajwani, A., Farooq, S. A., \& Bryant, V. M. (2014). Studies of bee foraging plants and analysis of pollen pellets from hives in Oman. Palynology, 38(2), 207-223.

Suryanarayana, M. C., Rao, G. M., \& Singh, T. S. M. S. (1992). Studies on pollen sources for Apis cerana Fabr and Apis mellifera L bees at Muzaffarpur, Bihar, India. Apidologie, 23, 33-46.

Thorp, W. R. (2000). The collection of pollen by bees (Apoidea). Plant Systematic and Evolution, 222, 211-223. 